\title{
Posterior Reversible Encephalopathy Syndrome During Acute Lymphoblastic Leukemia Treatment
}

Olgu Sunumu Case Report

Received/Geliş: 15.03 .2021 Accepted/Kabul: 28.05.2021 Published Online:

Eda Ataseven Ege Üniversitesi Tıp Fakültesi, Çocuk Sağlığı ve Hastalıkları ABD, Çocuk Hematolojisi ve Onkolojisi Bilim Dalı, İzmir - Türkiye edataseven@yahoo.com ORCID: 0000-0003-3419-5814

S. Atamyıldız 0000-0002-4283-0921 Ege Üniversitesi Tıp Fakültesi, Çocuk Sağlığı ve Hastalıkları $A B D$, İmir, Türkiye

C. Erarslan 0000-0002-5762-6149 Ege Üniversitesi Tıp Fakültesi, Radyoloji Anabilim Dalı, Izmir, Türkiye

M. Kantar 0000-0002-1669-4321 Ege Üniversitesi Tip Fakültesi, Çocuk Sağlığı ve Hastalıkları Anabilim Dalı, Çocuk Hematolojisi ve Onkolojisi Bilim Dali, Izmir, Türkiye

Cite as: Atamyildız S, Ataseven E, Erarslan C Kantar M. Posterior reversible encephalopathy
syndrome in two cases with acutelymphoblastic leukemia. Tepecik Eğit. ve Araşt. Hast. Dergisi. 2021;31(3):416-20.

\section{Akut Lenfoblastik Lösemi Tedavisi Sırasında Posterior Reversible Ensefalopati Sendromu Gelişen Olgularımız}

\author{
Sıla Atamyıldız $\odot$, Eda Ataseven $\odot$, Cenk Erarslan $\odot$, Mehmet Kantar $\odot$
}

\begin{abstract}
Posterior reversible encephalopathy syndrome (PRES) is a clinical and radiological syndrome, characterized by acute onset of headache, altered mental status, visual impairment, nausea, vomiting, seizure, and hypertension. PRES is a reversible condition if it is recognized early, but neurological damage or even death may occur. Herein, we present two cases of ALL who developed PRES during their induction therapy and a literature review of PRES.

Keywords: Posterior reversible encephalopathy syndrome, ALL, childhood

Öz

Posterior reversible ensefalopati sendromu (PRES), akut başlangıçlı baş ağrısı, mental durum bozukluğu, görme bozukluğu, bulantı, kusma, nöbet ve hipertansiyon ile karakterize klinik ve radyolojik olarak tanımlanmış bir sendromdur. PRES erken farkedildiğinde geri dönüşümü olan bir durumdur. Ancak bazı vakalarda kalıcı nörolojik hasara hatta ölüme bile yol açabilir. Burada, ALL indüksiyon tedavisi sırasında PRES gelişen iki olguyu literatür ile beraber değerlendirdik, ALL tedavisi sırasında karşılaşabileceğimiz bu önemli duruma dikkat çekmeyi ve farkındalığı arttırmayı hedefledik.
\end{abstract}

Anahtar kelimeler: Posterior reversible ensefalopati sendromu, ALL, çocukluk

\section{INTRODUCTION}

Posterior reversible encephalopathy syndrome (PRES) is a clinical and radiological syndrome, first described in 1996, characterized by acute onset of headache, altered mental status, visual impairment, nausea, vomiting, seizure, and hypertension (1). The main pathophysiological underlying cause is still unknown, but the dysfunction of the endothelium and blood-brain barrier is the dominant entity ${ }^{(2)}$. There are many etiological factors for PRES, these include hypertensive encephalopathy, malignancy, stem cell and solid organ transplantations, immunosuppressive and cytotoxic drugs, autoimmune diseases and collagen vascular diseases (2-5). For pediatric patients, the most common causes of PRES are acute leukemia, glomerulonephritis, Henoch Schoenlein purpura, and hemolytic uremic syndrome. Acute lymphoblastic leukemia (ALL) patients make up 1.6 to $4.5 \%$ of PRES cases, and PRES mostly occurs during the first three months of therapy (2). On magnetic resonance imaging (MRI) scan, T2-weighted and FLAIR sequences show vasogenic edema that mostly involves the white matter of the posterior parts of temporal and (c) Telif hakkı T.C. Sağlık Bakanlı̆ı İzmir Tepecik Eğit. ve Araşt. Hastanesi. Logos Tıp Yayıncııık tarafindan yayınlanmaktadır. Bu dergide yayınlanan bütün makaleler Creative Commons Atff-GayriTicari 4.0 Uluslararası Lisansı ile lisanslanmıștır.

(c) Copyright Association of Publication of the T.C. Ministry of Health Izmir Tepecik Education and Research Hospital. This journal published by Logos Medical Publishing. Licenced by Creative Commons Attribution-NonCommercial 4.0 International (CC BY-NC 4.0) 
occipital lobes of the brain ${ }^{(1,6,7)}$. PRES is a reversible condition if it is recognized early, but still neurological damage or even death may occur ${ }^{(6)}$.

In this report, we present two cases of ALL who developed PRES during their induction therapy and a literature review of PRES.

\section{CASE 1}

A 3-year-old female patient presented with bilateral non-tender cervical lymphadenopathy and hepatosplenomegaly was diagnosed with pre-B ALL and started ALL IC-BFM 2009 protocol. On her diagnosis, her white blood cell count was 29.600/ $\mathrm{mm}^{3}$ and her treatment response at day 8 was poor $\left(\geq 1000 / \mathrm{mm}^{3}\right.$ blast), and she became a high-risk patient. After her first HR1 block treatment including vincristine, cyclophosphamide, methotrexate, cytarabine, and L-asparaginase, she presented with neutropenia, abdominal pain, nausea, vomiting, and diarrhea symptoms and was diagnosed as typhlitis. Appropriate antibiotic therapy was given, and her gastrointestinal symptoms relieved.

In her follow-up, few days later, her blood pressure was elevated, her consciousness was altered, and she developed a right focal seizure. Her physical examination revealed upper sight paralysis, ptosis at her left eye, edema at the left side of her face. Laboratory examination of complete blood count and biochemistry were normal. A cranial MRI scan showed hyperintensity at both cortex and subcortex areas and white matter of occipital lobes in $\mathrm{T} 2$ and FLAIR sequences (Figure 1a-1b). Her cranial MRI scan suggested PRES, and she was started antihypertensive therapy with calcium channel blockers and anti-epileptic therapy with levetiracetam. An EEG was performed and reported diffuse slow waves in the frontotemporal and temporal parts of the left hemisphere, and paroxysmal slow waves in the frontocentral parts of the right hemisphere.

With the antihypertensive treatment, she became
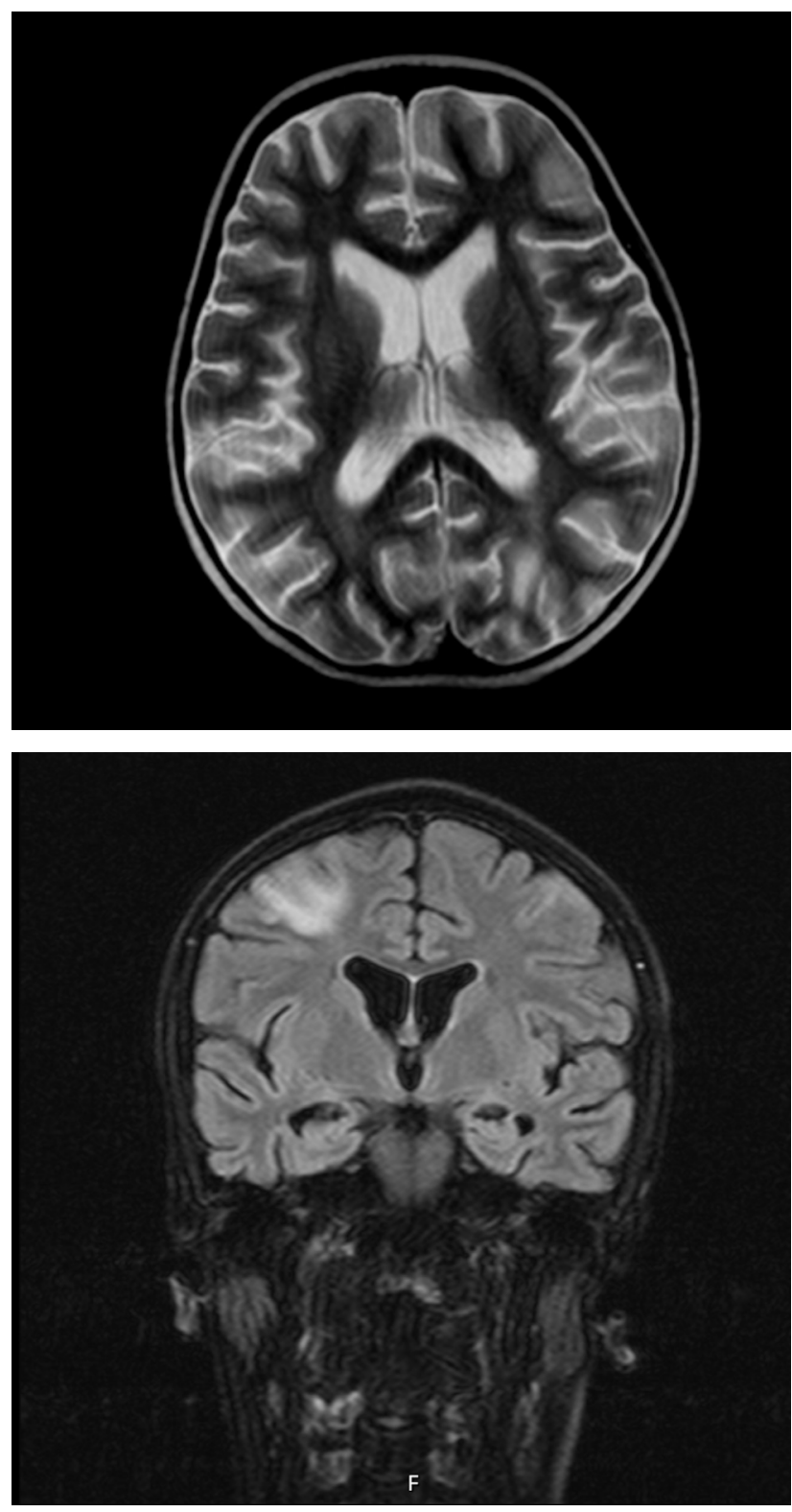

Figure 1.

a) MRI scan T2-weighted image showing hyperintense areas at parietal and occipital lobes.

(b) FLAIR images showing bilateral edema and hyperintense areas at parietal and occipital lobes.

(c) FLAIR scan showing no hyperintense areas.

normotensive, and her papillary examination showed no hypertensive retinopathy signs. Bone marrow aspiration and biopsy were performed and showed remission. A control MRI scan was performed after twenty days demonstrating all hyper-intense areas on scans were diminished (Figure 1c). She became asymptomatic, then ALL protocol was resumed with Block HR2 and her antihypertensive and anti-epileptic 
treatments were terminated.

Ten months later, she presented with a convulsion of orofacial involvement (salivation, lip-smacking, chewing) which was not controlled with intravenous midazolam, phenytoin, and le-vetiracetam. A cranial MRI scan was performed, and it suggested diffuse atrophy of bilateral cerebral hemispheres and bilateral dilation of the lateral ventricles. Ventriculoperitoneal shunt placement for hydrocephalus was performed by the neurosurgeons. Her chemotherapy protocol was completed, and no further complication was reported.

\section{CASE 2}

A 12-year-old female patient presented with fever and bone pain for the last 20 days. On her physical examination, she had pallor, bilateral submandibular lymphadenopathy, and hepatosple-nomegaly. Her white blood cell count was $11.890 / \mathrm{mm}^{3}$, whereas herabsolute neutrophil count $1680 / \mathrm{mm}^{3}$, hemoglobin $12.1 \mathrm{gr} / \mathrm{dl}$, and platelet $44.000 / \mathrm{mm}^{3}$. Her peripheric blood smear revealed $48 \%$ of lymphoblasts, and her bone marrow aspiration showed $72 \%$ of L1 type of lymphoblasts. The cerebrospinal fluid examination was normal. Immunophenotyping suggested a pre-B ALL. Induction phase of ALL IC-BFM 2009 protocol which includes prednisolone; vincristine, and doxorubicin, L-asparaginase and intrathecal methotrexate was started.

On day 29 of Protocol $1 \mathrm{~A}$ induction phase, she had a slightly elevated blood pressure, and developed sudden onset of a generalized tonic-clonic seizure which was managed with phenytoin. Her laboratory markers. A computed tomography scan of the brain showed hypo-intense changes at the right side of the brain. A cranial MRI scan was performed and revealed hyper-intense areas in both cerebral hemispheres and widespread contrast enhancement in the occipital areas on T2 and FLAiR sequences, which correlated with PRES (Figure 2a-2b). During her follow up on day 30 , her blood pressure levels were not controlled completely, a second seizure occurred
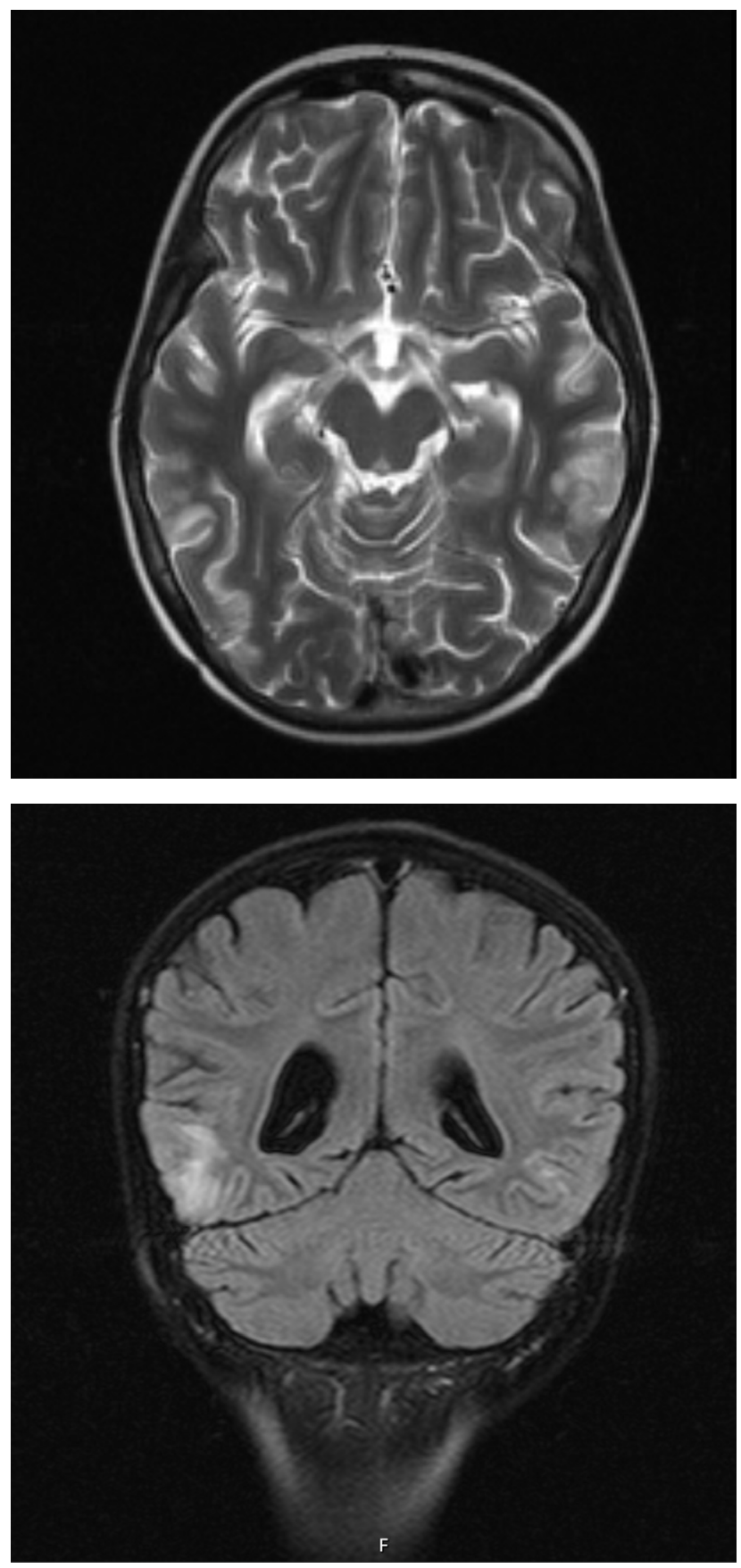

Figure 2.

(a) MRI scan T2-weighted image showing hyperintense areas at parietal and occipital lobes.

(b) FLAIR scan showing bilateral hyperintense areas at occipital lobes.

which started focally, then progressed to generalized tonic-clonic seizure. With the worsening of her clinical status, somnolence, and uncontrolled blood pressure, she was admitted to the pediatric intensive care unit. EEG demonstrated isolated sharp waves in the left hemisphere. She continued on anti-epileptic 
treatment levetiracetam and antihypertensive treatment as amlodipine, and no complication was reported.

\section{DISCUSSION}

The overall incidence of PRES related hospital administrations in pediatric patients, is $0.04 \%{ }^{(8,9)}$. In the largest population-based cohort study, the mean age at presentation is $12.54 \pm 0.19$ years, which shows PRES is more common in adolescent groups. Females are more prone to have PRES than males ${ }^{(9,10)}$.

The diagnosis of PRES comprises both clinical manifestations and radiological data. Clinical manifestations include hypertension, acute neurological deterioration such as headache, altered mental status, diplopia, visual disturbance, tremor, ataxia or seizures ${ }^{(11,12)}$. Hypertension is one of the most prominent signs of PRES, but nearly $20 \%$ of the patients have normal blood pressure ${ }^{(12)}$. Most of the patients have a generalized tonic-clonic type of seizure, which shows nonspecific encephalopathic changes or bilateral/unilateral parieto-occipital sharp waves on electroencephalogram ${ }^{(2,8,13)}$. The diagnosis is confirmed with the radiological findings on MRI which typically include bilateral vasogenic edema at the posterior regions of cerebral hemispheres, predominantly but not restricted to the parietooccipital lobes ${ }^{(8,15)}$.

Characteristic neurological images on MRI are bilateral hyperintense areas of the parieto-occipital lobes of the brain at T2-weighted and FLAIR imaging ${ }^{(7,8)}$. The neuroimaging workup shows vasogenic edema in the subcortical white matter mostly on parieto-occipital lobes ${ }^{(16)}$. Atypical involvement regions of the brain are the brain stem, basal ganglia, thalamus, internal capsule, cerebellum, and splenium of the corpus callosum ${ }^{(13)}$.

The underlying mechanism of posterior reversible encephalopathy syndrome is still not fully understood. One of the main pathophysiological hypothesis of PRES is the blood-brain barrier dysfunction, caused by a sudden rise in blood pressure ${ }^{(2,17)}$. With elevation of the blood pressure, the autoregulatory capacity of the brain is disrupted which results in cerebral vasogenic edema ${ }^{(6)}$. The other hypothesis is the direct cytotoxic effects of the antineoplastic and immunosuppressive drugs, which are methotrexate, vincristine, cyclophosphamide, cyclosporin, tacrolimus, and sirolimus ${ }^{(14)}$. These agents cause a direct cytotoxic effect on the vascular endothelium and affect the endothelial system ${ }^{(5,6,18)}$. Eventually, both mechanisms disrupt the blood-brain barrier, and increase the leakage of the plasma and the red blood cells into the cerebrovascular space to the intercellular space and cause vasogenic edema ${ }^{(17,19)}$.

The etiological factors of PRES are hypomagnesemia, hypercalcemia, hyponatremia, high dose methylprednisolone therapy, Henoch-Schöenlein purpura, sickle cell disease, stem cell and solid organ transplantation, hemophagocytic lymphohistiocytosis, and chronic renal failure. A study of 825 hospitalized pediatric patients with the diagnosis of PRES have been made to differentiate the incidences of the underlying causes ${ }^{(9)}$. The incidences of PRES are $0.3 \%$ in solid organ transplant patients, $0.4 \%$ in primary immune deficient patients and $0.1 \%$ in hematological malignancy patients ${ }^{(9)}$. According to another study with 112 patients with malignancy affected with PRES, the incidence of PRES was $2.1 \%$ in acute lymphoblastic leukemia and $4.7 \%$ in hematopoietic stem cell transplantation ${ }^{(7)}$.

The most common type of malignancy to cause PRES is ALL then lymphoma and acute myeloid leukemia ${ }^{(10)}$. Majority of the cases show symptoms within 6 months and mostly first month after start of chemotherapy. ALL treatment protocols include high dose of glucocorticoids and other antineoplastic drugs that have direct cytotoxic effect on the bloodbrain barrier.

Anastasopoulou et al. studied 52 patients who developed PRES, among 1378 acute lympho-blastic leukemia patients treated with Nordic Society of Pediatric Hematology and Oncology (NOPHO) ALL- 
2008 protocol, for their clinical characteristics, risk factors, course, and outcome of the disease. It has been found that older age (younger age group 1-9 years old, older age group 10-17 years old), T-cell leukemia, CNS involvement at diagnosis, and highrisk treatment were all found significant risk factors for PRES ${ }^{(2)}$. For both of our patients, involving in the older age group was a risk factor.

Seizures are the most common manifestation of $80 \%$ of PRES cases, and sometimes the pre-senting symptom may be status epilepticus ${ }^{(2,20)}$. For our patients, a seizure was a prominent symptom. One case had elevated blood pressure values and the other had not.

Supportive care and secondary prophylaxis are the mainstays to treat PRES cases. For each symptom, associated therapy is recommended. Since nearly $80 \%$ of patients with PRES are hyper-tensive at the administration, one of the major goals is to stabilize blood pressure with antihypertensive medications. To prevent cerebral hypoperfusion, aimed blood pressure should be achieved within two to six hours, and not to exceed a blood pressure drop more than 25 percent in the first hours ${ }^{(8)}$. For seizures, antiepileptic therapy is given. If the patients have repeated active seizures, intravenous benzodiazepines are used for first-line antiepileptic drugs. For the secondary prophylaxis of antiepileptic therapy, phenobarbital, levetiracetam, and valproic acid can be given. Only minority of patients need a long-term antiepileptic treatment ${ }^{(7)}$.

In conclusion, PRES is a reversible condition if it is recognized early. It should be considered in pediatric leukemia patients who develop systemic hypertension, altered consciousness, blurred vision, and new-onset seizures.

Conflict of Interest: The authors declared no conflict of interest.

Informed Consent: Informed consent forms were taken from the patients.

\section{REFERENCES}

1. Hinchey J, Chaves C, Appignani B. A reversible posterior leukoencephalopathy syndrome. N Engl J Med. 1996;334(8):494500. [CrossRef]

2. Anastasopoulou S, Eriksson MA, Heyman M, et al. Posterior reversible encephalopathy syn-drome in children with acute lymphoblastic leukemia: clinical characteristics, risk factors, course, and outcome of disease. Pediatr Blood Cancer. 2018;66(5):1-10. [CrossRef]

3. Khan SJ, Arshad AA, Bilal M. Posterior reversible encephalopathy syndrome in pediatric cancer: clinical and radiologic findings. J Glob Oncol. 2017;(4):1-8. [CrossRef]

4. Nilgun E, Aysenur B, Erol E. A case of ALL developing posterior reversible encephalopathy secondary to hyponatremia. J Pediatr Hematol Oncol. 2017;39(8):476-8. [CrossRef]

5. Musioł K, Waz S, Boron $\mathrm{M}$, et al. PRES in the course of hematooncological treatment in children. Child's Nerv Syst. 2018;34:691-9. [CrossRef]

6. Tambasco N, Mastrodicasa E, Salvatori C, et al. Prognostic factors in children with PRES and hematologic diseases. Acta Neurol Scand. 2016;134(6):474-83. [CrossRef]

7. Zama D, Gasperini P, Berger M, Petris M. A survey on hematologyoncology pediatric AIEOP centres: the challenge of posterior reversible encephalopathy syndrome. Eur J Haematol. 2018;100(1):75-82. [CrossRef]

8. Chen TH. Childhood Posterior Reversible Encephalopathy Syndrome: Clinicoradiological Characteristics, Managements, and Outcome. Front Pediatr. 2020;8(September):1-11. [CrossRef]

9. Thavamani A, Umapathi KK, Puliyel M, Super D, Allareddy V, Ghori A. Epidemiology, comorbidities, and outcomes of posterior reversible encephalopathy syndrome in children in the united states. Pediatr Neurol. 2020;103:21-6. [CrossRef]

10. Hafez HA, Ragab I, Sedky M, et al. Patterns, risk factors and outcome predictors of posterior reversible encephalopathy syndrome in pediatric cancer patients. Leuk Lymphoma. 2020;62(2):462-8. [CrossRef]

11. Ghali MGZ, Davanzo J, Leo M, Rizk E. Posterior reversible encephalopathy syndrome in pediatric patients: pathophysiology, diagnosis, and management. Leuk Lymphoma. 2019;60(10):236572. [CrossRef]

12. Panis B, Vlaar AMM, Van Well GTJ, et al. Posterior reversible encephalopathy syndrome in paediatric leukaemia. Eur J Paediatr Neurol. 2010;14(6):539-45. [CrossRef]

13. Raj S, Overby $P$, Erdfarb A, Ushay HM. Posterior reversible encephalopathy syndrome: In-cidence and associated factors in a pediatric critical care population. Pediatr Neurol. 2013;49(5):335-9. [CrossRef]

14. Chen TH, Lin WC, Tseng YH, Tseng CM, Chang TT, Lin TJ. Posterior reversible encepha-lopathy syndrome in children: case series and systematic review. J Child Neurol. 2013;28(11):1378-86. [CrossRef]

15. Faille L della, Fieuws S, Van Paesschen W. Clinical predictors and differential diagnosis of posterior reversible encephalopathy syndrome. Acta Neurol Belg. 2017;117(2):469-75. [CrossRef]

16. Gümüş $H$, Per $H$, Kumandaş $S$, Yikilmaz A. Reversible posterior leukoencephalopathy syn-drome in childhood: report of nine cases and review of the literature. Neurol Sci. 2010;31(2):125-31. [CrossRef]

17. Zou L-P, Liu L-Y, Li H, et al. Establishment and utility assessment of posterior reversible encephalopathy syndrome early warning scoring (PEWS) scale establishment and utility as-sessment of PEWS scale. BMC Neurol. 2019 Dec 21;19(1):30. [CrossRef]

18. Emeksiz S, Kutlu NO, Çaksen H, Alkan G, Yıkmaz HŞ, Tokgöz H. Posterior reversible en-cephalopathy syndrome in children: a case series. Turk Pediatr Ars. 2016;51:217-20. [CrossRef]

19. Kim SJ, Im SA, Lee JW, et al. Predisposing factors of posterior reversible encephalopathy syndrome in acute childhood leukemia. Pediatr Neurol. 2012;47:436-42. [CrossRef]

20. Hinduja A, Habetz K, Raina SK, Fitzgerald RT, Sahaya K. Predictors of seizures in patients with posterior reversible encephalopathy syndrome. Epilepsy Behav. 2016;61:97-101. [CrossRef] 